\title{
LANGUAGE USE BETWEEN MALE AND FEMALE HOST IN HITAM PUTIH TALK SHOW
}

\author{
Nurmaliana Sari \\ Sumarsih \\ Busmin Gurning
}

Diterima Mei 2018; Disetujui Juni 2018; Dipublikasikan Agustus 2018

\begin{abstract}
This study discusses about language use occurred by male and female host in Hitam Putih talk show. The research is conducted by applying qualitative descriptive design. The subjects of this study are male and female host in Hitam Putih talk show. The data are the utterances produced by male and female host in Hitam Putih talk show. This research focuses on the show broadcasted on October 2016 by taking 4 videos randomly. The objectives of this study are (1) to describe kinds of the language use uttered by male and female host in Hitam Putih talk show, (2) to elucidate language use represented by male and female host in Hitam Putih talk show and (3) to describe reasons of different language use by male and female host in Hitam Putih talk show in the ways they are. Additionally, the data are analyzed by applying theory of Interactive Model. The findings showed that the kinds of language use consist of 6 parts such as specialized vocabulary, expletives, empty adjectives, tag questions, polite form and telling joke or humor. The dominant language use uttered by male host is expletive, because male's utterances are frequently stated in a negative connotation. There are common expressions generally referring to English expletives such as: bad language, profanity, swearwords, cursing, foul language, etc. On the other hand, female host utterances are found in specialized vocabulary as the most dominant because female host has more interest in talking family affairs, such as the education of children, clothes, cooking, and fashion, etc. Women also tended to talk about one thing related to the home and domestic activities. However, the representation of language use uttered by male and female are deficit, dominance and different. And the reason of this matter because of some factors such as psychology and different social status.
\end{abstract}

Key words: Language use, Gender, Talk show

How to Cite: Nurmaliana Sari (2018).Language Use Between Male and Female Host in Hitam Putih Talk Show.Jurnal Linguistik Terapan Pascasarjana Unimed, 15 (2): 148-156 


\section{INTRODUCTION}

Language has a very complicated system which is a pattern for the structure of the society. Not only do people use language to express their thoughts and feelings, but also they are given different identities and able to describe their communications through using language. Due to the fact that language is a social phenomenon, it is strongly influenced by social and cultural factors such as gender, age, educational level, social level and so forth.

One of the primary functions of language is to enable man to describe the world or to communicate with other people. On the other hand, language reflects, if it does not determine, the thoughts, attitudes, and culture of the people who make and use it. In this sense, language needs to be viewed as a social practice. Further Zendedel and Ebrhimi (2013) states that language as well as is inherently social phenomenon which provides insights into how men and women's language use can affect their social.

In this research, the researcher concerned on language use by applying theory proposed by Lakoff (1975) and Wardhaugh (2006). The researcher quotes several utterances from the host in Hitam Putih between male, Deddy Corbuzier (DC) and female host, Chika Jessica (CJ) as the preliminary data as follows;

CJ : Karena kita kompak, terus kita blue blue (their clothes) gak pake bird ya (said to the audience).

DC : (tersenyum). (just smile).

From the utterances above, it can be shown that $\mathrm{CJ}$ attempts to tell joke to the audience. Theory of language use adapts from Lakoff (1975) and Wardhaugh (2006) state that woman is lack in uttering some joke or telling humor. As the fact, CJ is easily to utter some jokes which affect the audience at the studio and her partner (DC) laugh. She says that the audience and herself is to be together because they wear the same color, blue. Then, she makes a joke that "blue" is not needed to add "bird" because it will change the meaning become "blue bird" as one of the name of taxi.

In other utterances between DC, male host and his guest (AS), he wanders about her husband's traits.

\section{DC : Jadi menurut kamu mas Anang ini romantis gak orang nya?}

Base on the utterances above, it can be identified that male host somehow fells interested in discussing about someone's accustomed. However those topic includes to the feminine area that discuss about personal life. He wanders to know more about her husband so he asks the guest intensely. Further it should be asked and confirmed by the female host (CJ) relating to their guest life. But it is found that male host directly ask their guest.and he has much more curiosity to know. And base on the theory man are not really interested to discuss or share about someone's life. 
In guiding the show, the host should use an appropriate language use in order to make the show running well and build a warm relationship between host and guest. They also make adjustments depending on whom they are talking to. In choosing which speech forms to use, they asseses not only the relative formality or informality of the context, but also the audience to whom their talk is directed. The accommodations speakers should towards their audiences depend on the social status of the participants (Romain, 2000).

Gender as one of the primary category that people use to understand and think about their social world. Gender refers to the relationship between men and women or male and female. According to Gal (1991) gender is a system of culturally constructed relations of power, produced and reproduced in interaction between men and women. However, Wardhaugh (2006) conveys gender as a social construct and involves the whole gamut of genetic, psychological, social and cultural differences between males and females. Gender can not be avoided. It is part of the way in which societies are ordered around us, with each society doing the ordering differently.

Language and gender theorists have generally made a distinction between sex as physiological, and gender as a cultural or social construct. According to this distinction, sex refers to biological maleness and femaleness, or the physiological, functional, anatomical differences that distinguish men and women, whereas gender refers to the traits assigned to a sex - what maleness and femaleness stand for - within different societies and cultures (Litosseliti, 2013).

Generally, language use is produced by male and female occurred in distinct ways. There are some characteristics come about between male and female. In this case the researcher applies theory proposed by Lakoff (1975) and Wardhaugh (2006) in which they state that one of the characteristic language use by man, they tend to make a joke, teasing other people whereas women can not tell jokes - they are bound to ruin the punch line, they mix up the order of things, and so on. Moreover, they don't "get" jokes. In short, women have no sense of humor rather than a man.

In order to undergo this research, researcher gathers the data taken from one of talk show, Hitam Putih, broadcasted in Trans7. By adapting this theory the researcher takes several utterances from the host in Hitam Putih between Male host, Deddy Corbuzier (DC) and female host, Chika Jessica (CJ). Researcher focuses on their utterances produced by the host Hitam Putih talk show.

Hitam Putih talk show is a program broadcasted in Trans7 channel on monday till friday at 18.30-19.45. Hitam Putih is guided by a mentalist Deddy Corbuzier and an artist Chika Jessica. In this talk show, it emerges an inspiration story not only come from Indonesian artists but also from an ordinary people with a ton of proudly achievement. Sometimes in fasting month, this show also invites some religious leaders in order to convey useful lecture to the audience. However Hitam Putih talk show has been several times included as list of nomination and achieved the winning as the TV Program of the Year, Program Talk show Hiburan and Program Inspiratif Terpopuler. 
There are numerous studies that had been conducted concerns with language use, such as the research conducted byXia (2013) entitled Gender differences in using language. She analyzes the differences between men and women in using language. Base on her research, she discovers that the differences emerge from the aspects of pronunciation, intonation, vocabulary, syntax, manners, attitudes, and non-verbal differences in using language between men and women. Besides the differences in various aspects, she tries to record the changes of these differences. On the basis of these differences and changes, the study also tries to make some explanation to these differences and changes.

Another study Dong (2014) reveals on "Study on Gender Differences in Language under the Sociolinguistic" found that gender differences in utterance-choosing for instance, pronunciation and intonation difference, vocabulary difference, and syntactic difference. The gender difference phenomena in language reflect that the cultural psychology and social value orientation of language users are affected not only by social and environmental stress but also family culture and experience. The gender differences in language are not invariable. They are influenced by the age, education degree, occupation and status and change according to social development.

\section{RESEARCH METHOD}

This study was conducted by using qualitative research. Qualitative research is empirical research where the data are not in the form of numbers (Punch, 1998). It could be described as an event, persons and others scientifically research without the use of numerical data. Qualitative research was concerned on collecting and analyzing information in as many forms, chiefly nonnumeric, as possible. It tended to focus on exploring, in as much detail as possible, smaller numbers of instances or examples which are seen as being interesting or illuminating, and aims to achieve 'depth' rather than `breadth' (Blaxter, Hughes and Tight, 1996).

In addition, Gall, Gall, and Borg (2003) illuminate that qualitative research shows generate verbal or word and pictorial data to represent the social phenomena and use of analytic induction to analyze data. However this study contained the data in form of words rather than number. This research concerned on the utterances of male and female host particularly in Hitam Putih talk show on Trans7. In which the data collection in the form of word and it was be analyzed in the form of word too.

\section{FINDINGS AND DISCUSSIONS}

Based on the analysis above, there were some findings could be revealed as the following;

1. Both of male and female host in Hitam Putih talk show elucidated the distinction kind of language use while they asked, commented, shared, discussed or even interacted not only for the audience, but also guest and somebody else. Kinds of language use were produced by 
male and female host tended to slightly different in some characteristics for instance, specialized vocabulary, expletive, empty adjective, tag question, polite form and joke. The most dominant kinds of language use uttered by male host was expletive. Most of his utterances were indicated to the expletive word, hence he attempted to interact or respond his guest or even the audience by delivered expletive form. On the other hand women tended to use specialized vocabulary. She tended to discuss relating to the feminine area. However there were some utterances that can be classified based on the theory, it was Satirize form. Satirize form can be categorized as the utterances that used to satirized the guest about his activity or some their behavior that they did. Somehow, male host curious about women topic. He wandered to know more about it then he discussed together with the guest. Further, he asked the female guest relating about their wealth, beauty that involved to the feminine area.

2. The discussion of representation in language use by male and female host were divided into three parts namely; deficit, dominance and different. Male and female host tended to represent the language use in the different term. It was caused that male and female host have to share, inform, discuss and giving such a motivation and solution. However, they attempted to convey an impression and useful show to the audience.

3. The distinctions of language use were caused by some factors different psychology and different social status. Somehow those factors showed that the man more direct, rude, and use the expletive word to explain what in his mind rather than women who felt more sensitive and considerate. Before a woman talked, they usually thought the effect her words would cause something, so she often emerged to be more polite. On the contrary, men appeared to be rash, and they just conveyed what they wanted to say and seldom cared what others think, so men's speech tended to blunt and solid.

By relating the analysis above, researcher discovered some hint that necessary to be discussed, male host was very detail and sensitive while he commented or asked about one topic or theme that he really interested in. It could be stated that men wandered to know every particular object toward to the guest or one news eventhough it tended to women area such as beauty or fashion. On the other hand women just concerned on her area like, fashion, family, beauty and others. This characteristic could be one of new findings that male host was very detail and wandered for every particular things. For the concept of kinds of language use, Lakoff elucidated that women did not have any sense in conveying some joke or even telling humor. Moreover, women tended to ruin the line of humor. Nevertheless that female host showed her ability to calm the situation or even to create a relax condition by conveying some joke to her partner. Consequently, her joke make the audience, guest and even her partner laugh and enjoy the situation. 
Based on the previous study, Xia (2013) has conducted a research entitle Gender differences in using language. She discovered the differences between men and women in using language. Based on her research she found that the differences emerge from the aspects of pronunciation, intonation, vocabulary, syntax, manners, attitudes, and non-verbal differences in using language between men and women.

Further, Onem (2014) on his research about gender differences in the length of requests in Turkish found that women had a tendency to include more details and men tended to be more direct. It also shows a statistically significant difference between the female and male participants in the number of words used in total and for each request, in favor of females.

In this study, researcher attempted to discuss deeper include the kinds of language use produced by male and female in the form of Satirize. Male host utterances were elucidated by satirized. He often to satirize and even offended his guest to communicate, ask, or even respond to his guest's statement.

On the other hand, female host tended to calm the situation while her partner got angry. She attempted to maintain the conversation and built a harmonious situation. She delivered much more respond to calm the situation. Furthermore she attempted to give a respond that she was really listening to the guest and want to maintain a conversation for more.

Furthermore, the representation of language use produced by male and female host tended to represent the language use in the different term. It was caused that male and female host have to share, inform, discuss and giving such a motivation and solution. However, they attempted to convey an impression and useful show to the audience. In line with the theory the male host more active and wise to deliver an advice. He also attempted to encourage the audience to take positive effect that was gained from the guest. On the other hand, women were likely to calm the situation when her partner, Deddy, get angry or annoyed toward something. She was going to calm her partner so the show can run well and the audience would to enjoy it.

And the last point that can be discussed from the findings were the reason of language use differences between male and female host such psychology, different social status and different cultural background. As the psychology, women tended to build a harmonious situation with her guest. She attempted to reduce something that make her guest get satirize. Otherwise male host too directly and open minded while he asked or comment to his guest. He did not need to think twice if his utterances would affect the guest annoyed or not. The point that can be gained from the findings were somehow both of the host often to satirize each other to build and create some joke. Somehow, they often to satirize their guest just to create a comfort situation by utterances some joke. 


\section{CONCLUSIONS}

This study was concerned about the language use occurred between male and female host in Hitam Putih talk show on Trans7. This research aimed to reveal how male and female host produce language use while they interacted, asked or even commented and to elucidate the reason of the language use distinction uttered by male and female host in the way they were. By accomplishing the analysis, there were some findings could be drawn as the following;

4. Both of male and female host in Hitam Putih talk show elucidated the distinction kind of language use while they asked, commented, shared, discussed or even interacted not only for the audience, but also guest and somebody else with some characteristics namely, specialized vocabulary, expletive, empty adjective, tag question, polite form and joke. The most dominant kinds of language use uttered by male host was expletive. On the other hand women tended to use specialize vocabulary. Somehow male host wondered to know more about feminine area such as wealth, beauty, etc.

5. The representation of language use produced by male and female host divide into three parts namely; deficit, dominance and different. Male and female host tended to represent the language use in the different term. It was caused that male and female host have to share, inform, discuss and give such a motivation and solution. However, they attempted to convey an impression and useful show to the audience.

6. The distinctions of language use were caused by some factors different psychology and different social status. Somehow those factors showed that the man more direct, rude, and use the expletive word to explain what in his mind. Otherwise woman usually thought the effect her words would cause something, so she often emerged to be more polite.

\section{REFERENCES}

Alami, M. (2016). Approaches to Gender Studies: A review of literature. Journal of Applied Linguistics and Language Research.Vol 3, Issue 3. Retrieved from:https://www.google.co.id/url?sa=t\&rct=j\&q=\&esrc=s\&source=web\&cd=1\&cad=r ja\&uact $=8 \&$ ved $=0$ ahUKEwjm uA-

KzTAhWGkpQKHZt7BUIQFggmMAA\&url=http\%3A\%2F\%2Fwww.jallr.com\%2Fin dex.php\%2FJALLR\%2Farticle\%2Fdownload\%2F271\%2Fpdf271\&usg=AFQjCNGsq1 GOAHOLIK6yRDZZOx9zX4AsEg

Al-Harahsheh, A, M, A. (2014). Language and Gender Differences in Jordanian Spoken Arabic: A Sociolinguistics Perspective. Theory and Practice in Language Studied. Vol. 4, No. $5 . \quad$ Retrieved from http://www.academypublication.com/issues/past/tpls/vol04/05/03.pdf

Blaxter, L., Hughes, C., \& Tight, M. (1996). How to Research. Buckingham: Open University Press. 
Bogdan, R.C., \& Biklen, S.K. (2007). Qualitative Research for Education. An introduction to theory and methods $\left(5^{\text {th }} e d\right)$. Boston: Pearson Education.

Cholifah, Y, W., Heryanto, \& Citraresmana. (2013). Strong Expletives, Empty Adjectives and Tag Questions Usage as a Gender Marker in A Serial Film "F.R.I.E.N.D.S". International Journal of Language Learning and Applied Linguistics World (IJLLALW). Vol. 4 (4), 403-417. Retrieved from; http://www.ijllalw.org/finalversion4431.pdf

Coates, J. (2013). Women, Men and Language; a sociolinguistic account of gender differences in language $3^{\text {rd }}$ edition. Routledge; USA

Creswell, J, W \& Plano, V, L. (2007). Designing and Conducting Mixed Methods Research. Thousand Oaks, CA: Sage Publications, Inc.

Denzin, N. (1970) The Research Act in Sociology, Chicago: Aldine.

Dong, J. Y. (2014). Study on Gender Differences in Language Under the Sociolinguistics. Canadian Social Science, 10(3), 92-96. Available from: http://www.cscanada.net/index.php/css/article/view/4602 DOI: http://dx.doi.org/10.3968/4602

Gal, S. (1991). Between speech and silence: The problematics of research on language and gender. In Gender at the Crossroads of Knowledge: Feminist Anthropology in the Postmodern Era, ed. by M. di Leonardo. Berkeley: University of California Press.

Gall, M. D., Gall, J. P., \& Borg, W. R. (2003). Educational Research. Boston: Pearson Education, Inc.

Ilie, C. (2006). Talk show. Sweden: Orebro University. http://didattica.uniroma2.it/assets/uploads/corsi/143780/Talk_shows.pdf

Lakoff, R. (1975). Language and Woman's Place. Language in Society,2(1), 45-80. New York: Harper and Row.

Li, J. (2014). A Sociolinguistics Study of Language and Gender in Desperate Housewives. Theory and Practice in Language Studies, Vol. 4, No. 1, pp. 52-57. Retrieved from; http://www.academypublication.com/issues/past/tpls/vol04/01/tpls0401.pdf

Linclon, Y.S., \& Guba, E.G (1985). Naturalistic Inquiry. Sage; California.

Litosseliti, L. (2013). Gender and Language: Theory and Practice. USA: Routledge.

Mahmud, M. (2011). Language and Gender in English Language Teaching. TEFLIN Journal. Vol 21, No 2. http://journal.teflin.org/index.php/journal/article/view/40

Miles, M.B., Huberman, A.M., \& Saldana, J. (2014). Qualitative Data Analysis; A Method Source Book third edition. USA: Sage.

Mills, S. (2003). Gender and Politeness.Cambridge University Press: Cambridge. 
Nazir, B. (2012). Gender Pattern on Facebook: A Sociolinguistic Perspective. International Journal of Linguisics. Vol 4, no. 3 retrieved from; http://www.macrothink.org/journal/index.php/ijl/article/viewFile/1899/pdf

Ning, H., Dai, X., \& Zhang, F. (2010). On Gender Difference in English Language and Its Causes. Asian Social Science.Vol. 6, No. 2 retrieved from: http://citeseerx.ist.psu.edu/viewdoc/download?doi=10.1.1.833.4986\&rep=rep1\&type $=$ p df

Onem, E.E. (2014). A Study on Gender Differences in the Length of Requests in Turkish. Journal of Language and Linguistics Studies, 12 (2), 13-21. Retrieved from; http://www.jlls.org/index.php/jlls/article/view/437/247

Punch, K. (1998). Introduction to Social Research: Quantitatie and Qualitative Approaches. London, Sage.

Romain, S. (2000). Language In Society; An Introduction To Sociolinguistic Second Edition. New York: oxford University press.

Sargeant, H. (2007). Basic English Grammar; For English Language Learner Book 2. Singapore; Saddleback Educational Publishing.

Talbot, M. (1998). Language and Gender- An Introduction. Cambridge: Polity Press.

Timberg, B. M., \& Robert J. E. (2002). Television Talk: A History of the TV Talk Show. United Sates of America: University of Texas Press.

Wardhaugh, R. (2006). An introduction to sociolinguistic; Fifth Edition. USA: Blackwell. Retrieved from http://home.lu.lv/ pva/Sociolingvistika/1006648_82038_wardhaugh_r_an_introduction to_sociolinguistics.pdf

Wardhaugh, R., \& Fuller, J. M. (2015). An introduction to sociolinguistics $\left(7^{\text {th }}\right.$ ed.).USA: Wiley-Blackwell.

Wenjing, X. (2012). Study on gender differences in English. International Conference on Education Technology and Management Engineering,16-17, 218-221.

Xia, X. (2013). Gender Differences in Using Language. Theory and Practice in Language Studies, vol. 3 No. 8 PP 1485-1489. Finland. Retrieved from: http://www.academypublication.com/issues/past/tpls/vol03/08/28.pdf

Zendedel, A. A., \& Ebrhimi, S. (2013). Gender Differences In Language Usean Analysis Of Simin Daneshvar's Savushun. European Scientific Journal, 9(2).https://www.google.co.id/url?sa=t\&rct=j\&q=\&esrc=s\&source=web\&cd=1\&cad=rj a\&uact=8\&ved=0ahUKEwiQ1_Wg16jRAhUKO48KHUOmDXcQFggcMAA\&url=http $\% 3 \mathrm{~A} \% 2 \mathrm{~F} \% 2 \mathrm{Feujournal}$. org\%2Findex.php $\% 2 \mathrm{Fesj} \% 2$ Farticle\%2Fdownload $\% 2 \mathrm{~F} 722 \% 2$ F771\&usg=AFQjCNHiYLt-u0SXoj_3E9QOq1suhT1unA\&bvm=bv.142059868,d.c2I 